\title{
PENYUSUNAN PROGRAM APLIKASI INVENTARISASI POHON DI JALAN KH. RD. ABDULLAH BIN NUH BOGOR
}

\section{Construction of the Tree Inventory Application for Abdullah bin Nuh Street, Bogor City}

\section{Bambang Sulistyantara}

Departemen Arsitektur Lanskap, Fakultas Pertanian, IPB

e-mail : bbsulistyantara@yahoo.co.id

\section{Heru Rahmatullah}

Alumnus Departemen Arsitektur Lanskap, Fakultas Pertanian, IPB

\begin{abstract}
Road is a unit that must be completed, efficient, and attractive. It must have a circulation, a good interaction, and an exciting experience for the pedestrian. The road is also a place to plant trees. A line of trees can be planted on the roadside and median of road. Tree is a plant with woody stem and branch. Planting trees along of the road can provide a shelter and comfortable, reduce noise, and direct pedestrian path and vehicle path. Unfortunately, trees can arise some problems such as fallen trees and broken branche. The problem has happened at Abdullah bin Nuh street, Bogor City.In order to avoid and or minimize the risk of trees problem, it is needed to construct trees database in form of inventory application program. This research found a model of database application program forinventory of trees condition at Abdullah bin Nuh street. The advantage of program is that it can be applicated up to city scale and can record the number of trees up to 99.999. Beside, the program can be applicated for other cities in Indonesia.
\end{abstract}

Keywords: road tree, tree database, tree injury, tree inventory application, visual basic

\section{PENDAHULUAN}

Penanaman pohon di sepanjang jalur hijau jalan dapat memberikan suatu naungan, memberikan kenyamanan, mengurangi kebisingan, dan mengarahkan jalur pejalan kaki dan kendaraan. Penataan pohon juga dapat menimbulkan masalah seperti pohon tumbang atau dahan patah. Seperti halnya pohon yang terdapat di Jalan KH. Rd. Abdullah bin Nuh di Kota Bogor.

Pada 5 Januari 2012 di Jalan KH. Rd. Abdullah bin Nuh, Bogor Barat, dan Jalan Padjadjaran pohon tumbang dan dua pengendara motor lukaluka terkena patahan dahan pohon (Pos Kota, 2012). Untuk mengatasi hal tersebut diperlukan adanya pengelolaan dan pemeliharaan terhadap pohon di sepanjang jalan oleh pemerintah dan dinas terkait di Kota Bogor. Salah satu caranya adalah dengan menyusun aplikasi inventarisasi pohon.

Perkembangan teknologi komputer yang semakin pesat dapat membantu pemerintah dan dinas terkait dalam penyusunan aplikasi basis data inventarisasi pohon. Penyusunan aplikasi ini dapat memudahkan pihak terkait dalam menyusun jadwal pemeliharaan pohon kota. Berbagai data dan informasi mengenai beragam jenis, ukuran, dan kondisi pohon yang ada, khususnya di Jalan KH. Rd. Abdullah bin Nuh, Bogor dikumpulkan menjadi satu untuk selanjutnya diolah dan disusun dalam suatu aplikasi. Aplikasi inventarisasi pohon dapat dibuat dengan menggunakan software yang memiliki kemampuan tinggi untuk memasukkan data atribut, menyusun tampilan basis data, dan memasukkan data spasial.

Tujuan penelitian ini adalah menyusun aplikasi inventarisasi pohon di Jalan KH. Rd. Abdullah bin Nuh Kota Bogor yang dapat digunakan untuk menyimpan data pohon kota, sehingga lebih mudah dalam dikelola dan dipelihara.

\section{METODOLOGI}

\section{Lokasi dan Waktu Penelitian}

Penelitian ini berlokasi di sepanjang Jalan KH. Rd. Abdullah bin Nuh, Kota Bogor, Provinsi Jawa Barat. Pengambilan data dilaksanakan pada bulan April 2012. Kegiatan pembuatan basis data pohon digital dan penyusunan laporan dilaksanakan pada bulan April sampai bulan Mei 2012.

\section{Alat dan Bahan}

Alat yang digunakan terdiri atas perangkat keras (hardware) dan perangkat lunak (software). Perangkat keras (hardware) terdiri dari Notebook Fujitsu Siemens Esprimo Mobile U9200 (Intel Core 2 Duo T5250); Kamera digital 7.0 Mega Pixel merek Mpix; Klinometer untuk mengukur tinggi pohon; Rollmeter untuk mengukur diameter tajuk dan batang pohon; dan GPS (Global Positioning System) merk Garmin tipe GPSMap 76CSx untuk menentukan posisi eksisting pohon. Lalu, perangkat lunak (software) terdiri dari Microsoft Access 2010, Microsoft Excel 2010, Microsoft Visual Basic 2010, Map Info Professional 11.0, Garmin MapSource, Microsoft Office Picture Manager 2010.

\section{Metode Penelitian}


Penelitian dilaksanakan dengan beberapa tahap sebagai berikut:: (1) pengumpulan data pohon, (2) penyusunan aplikasi inventarisasi, dan (3) penyajian database pohon.

\section{Pengumpulan Data di Lapang}

Inventarisasi pohon dilakukan untuk memperoleh data sebagai berikut:

a. Diameter batang setinggi dada (DBH)

Pengukuran dilakukan dengan mengukur lingkar batang pohon setinggi dada $( \pm 140-145 \mathrm{~cm})$. Lalu dari hasil lingkar batang tersebut, baru dicari $\mathrm{DBH}$ menggunakan rumus lingkaran. Kemudian data $\mathrm{DBH}$ dikategorikan menjadi 4 kategori kelas (Tabel 1). Rumus untuk mencari DBH pohon adalah:

$$
\mathrm{DBH}=\frac{\kappa}{\pi}
$$

Keterangan:

DBH : Diameter batang setinggi

K : Keliling atau lingkar batang

pohon.

П : 3.14

b. Tinggi pohon

Tinggi pohon diukur menggunakan klinometer. Data dari klinometer berupa sudut pengamat. Melalui data tersebut, dapat dicari tinggi pohon menggunakan rumus trigonometri. Data tinggi pohon dikategorikan menjadi 3 kategori (Tabel 2).

Rumus untuk mencari tinggi pohon adalah:

$$
h=y+(s x \tan \alpha)
$$

\section{Keterangan:}

a :Sudut yang didapat menggunakan

klinometer.

$\mathrm{h}$ : Tinggi pohon (m).

$\mathrm{y}$ : Tinggi pengamat $(\mathrm{m})$.

$\mathrm{s}$ : Jarak pengamat dari titik pohon (m)

c. Lebar tajuk

Lebar tajuk diukur menggunakan rollmeter. Data lebar tajuk dikategorikan menjadi 4 kategori (Tabel 3).

d. Bentuk tajuk

Bentuk tajuk dibagi menjadi 8 kategori, yaitu bulat, kolumnar, dome, pyramidal, oval, bentuk $\mathrm{V}$, menjurai, dan spread (Gambar 1). e. Lokasi Pohon

Data lokasi pohon diperoleh menggunakan GPS dalam bentuk koordinat UTM X dan UTM Y. Data tersebut diolah dengan menggunakan MapInfo Professional 11.0 dan kerusakan mekanik. Nilai yang dihasilkan berupa persentase tingkat kerusakan. Kerusakan teknik hanya bisa diuraikan secara deskriptif berdasarkan pengamatan di lapang.

a. Kerusakan oleh hama dan

\begin{tabular}{|c|c|c|}
\hline Kelas & Kategori & Diameter $(\mathrm{cm})$ \\
\hline D1 & Semai & $\mathrm{DBH}<10$ \\
\hline D2 & Tiang (kecil) & $10 \leq \mathrm{DBH} \leq 30$ \\
\hline D3 & Hampir dewasa (sedang) & $30 \leq \mathrm{DBH} \leq 60$ \\
\hline D4 & Dewasa (besar) & $\mathrm{DBH}>60$ \\
\hline
\end{tabular}

Tabel 1. Kategori DBH Pohon

Sumber: Daniel, et. al. (1995) dalam Dinas Pertamanan Kotamadya Jakarta Timur (2006)

Tabel 2. Kategori Tinggi Pohon

\begin{tabular}{lll}
\multicolumn{1}{c}{ Kategori } & \multicolumn{1}{c}{ Kualifikasi } & \multicolumn{1}{c}{ Tinggi $(\mathbf{m})$} \\
\hline T1 & Rendah & $T<9$ \\
T2 & Sedang & $9 \leq \mathrm{T} \leq 18$ \\
T3 & Tinggi & $T>18$
\end{tabular}

Sumber: Carpenter, et. al. (1995)

Tabel 3. Kategori Lebar Tajuk

\begin{tabular}{lll}
\hline & \multicolumn{1}{c}{ Kategori } & \multicolumn{1}{c}{ Kualifikasi } \\
\hline L1 & Semai & $\mathrm{L}<2$ \\
L2 & Tiang (Kecil) & $2 \leq \mathrm{L} \leq 5$ \\
L3 & Hampir dewasa (Sedang) & $5 \leq \mathrm{L} \leq 9$ \\
L4 & Dewasa (Besar) & $\mathrm{L}>9$ \\
\hline
\end{tabular}

Sumber: Carpenter, et. al. (1995)

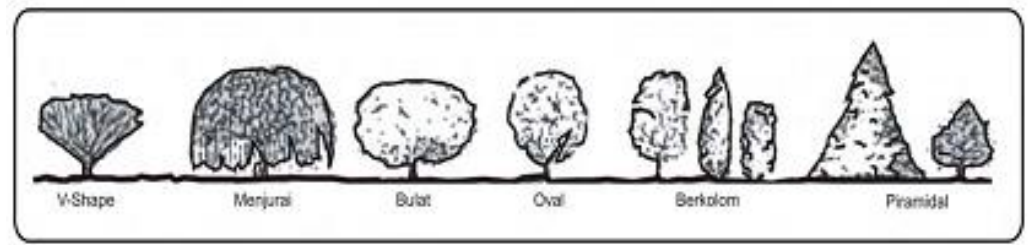

Gambar 2. Bentuk Tajuk Pohon (Carpenter et al, 1995)

sehingga dapat dipetakan pada peta rupa bumi digital.

\section{Penilaian Kondisi Fisik Pohon}

Data kondisi fisik pohon dibagi berdasarkan 3 jenis kerusakannya yaitu kerusakan yang disebabkan oleh hama dan penyakit tanaman, mekanik, dan teknik. Pengamatan kondisi fisik pohon dilakukan langsung secara visual mulai dari bagian pangkal akar batang di atas permukaan tanah, batang, daun, dan percabangan. Kondisi fisik pohon hanya dapat dinilai dari kerusakan oleh hama dan penyakit tanaman penyakit tanaman, penilaian tingkat kerusakan dibagi menjadi 2 bagian yaitu:

- Bagian pangkal akar di permukaan tanah dan batang (Tabel4).

- Bagian percabangan dan daun (Tabel 5).

Tingkat kerusakan pohon oleh hama dan penyakit tanaman pada pangkal akar dan batang dihitung dengan menggunakan rumus:

$$
\mathrm{T}_{\mathrm{ab}}=\frac{(\mathrm{nīx100)}}{\Sigma \text { ni }}
$$


Keterangan:

$\mathrm{T}_{\mathrm{ab}} \quad$ : Tingkat kerusakan pohon oleh hama dan penyakit tanaman pada pangkal akar dan batang

$\mathrm{n}_{\mathrm{i}} \quad$ : Nilai kerusakan pohon

$\sum \mathrm{n}_{\mathrm{i}}$ : Jumlah nilai kerusakan pohon oleh hama dan penyakit tanaman pada pangkal akar dan batang

Tingkat kerusakan pohon oleh hama dan penyakit tanaman pada cabang dan daun dihitung dengan menggunakan rumus:

$$
\mathrm{T}_{\mathrm{cd}}=\frac{(\mathrm{nix} 100)}{\sum \text { ni }}
$$

Keterangan:

$\mathrm{T}_{\mathrm{cd}} \quad$ : Tingkat kerusakan pohon oleh hama dan penyakit tanaman pada cabang dan daun

$\mathrm{n}_{\mathrm{i}} \quad$ : Nilai kerusakan pohon

$\sum \mathrm{n}_{\mathrm{i}}$ : Jumlah nilai kerusakan pohon oleh hama dan penyakit tanaman pada cabang dan daun

Setelah didapatkan nilai kerusakan pohon oleh hama dan penyakit tanaman pada pangkal akar dan batang $\left(\mathrm{T}_{\mathrm{ab}}\right)$ dan pada cabang dan daun $\left(\mathrm{T}_{\mathrm{cd}}\right)$, maka selanjutnya dapat dihitung total kerusakan pohon oleh hama dan penyakit tanaman menggunakan rumus:

$$
\mathrm{T}_{\mathrm{hpt}}=\frac{(\mathrm{Iab}+\mathrm{Icd})}{2}
$$

Keterangan:

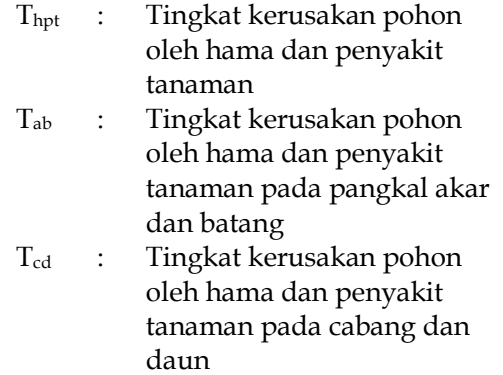

\section{b. Kerusakan mekanik}

Kerusakan mekanik pada pohon adalah kerusakan yang disebakan oleh kontak langsung dengan bendabenda fisik seperti goresan, gesekan, benturan, sayatan, dan sebagainya. Tingkat kerusakan mekanik dikate- gorikan dalam Tabel 6. Penghitungan tingkat kerusakan mekanik pohon dapat menggunakan rumus:

$$
\mathrm{T}_{\mathrm{m}}=\frac{(\mathrm{nix} 100)}{\sum \text { ni }}
$$

Keterangan:

$\mathrm{T}_{\mathrm{m}} \quad$ : Tingkat kerusakan mekanik pohon

$\mathrm{n}_{\mathrm{i}} \quad$ : Nilai kerusakan pohon

$\sum \mathrm{n}_{\mathrm{i}}$ : Jumlah nilai kerusakan mekanik pohon

Setelah terkumpulnya hasil dari penilaian kerusakan pohon yang disebabkan oleh hama dan penyakit tanaman serta kerusakan mekanik (Tabel 7). Maka total kerusakan pohon dapat dihitung dengan menggunakan rumus:

$$
\mathrm{T}=\frac{(1 \mathrm{npt}+\pi \mathrm{m})]}{2}
$$

Keterangan:

$$
\begin{array}{lll}
\mathrm{T} & : & \begin{array}{l}
\text { Tingkat kerusakan total } \\
\text { pohon }
\end{array} \\
\mathrm{n}_{\mathrm{i}}: & \begin{array}{l}
\text { Tingkat kerusakan pohon } \\
\text { oleh hama dan penyakit } \\
\text { tanaman }
\end{array} \\
& \begin{array}{l}
\text { Tingkat kerusakan mekanik } \\
\text { pohon }
\end{array}
\end{array}
$$

Melalui metode Grey dan Deneke (1978) yang telah dimodifikasi maka tingkat kerusakan total pohon dikategorikan berdasarkan peringkat, antara lain:

a. Peringkat 1 (sangat baik) Kondisi pohon sehat dan vigor sehingga tidak diperlukan tindakan perawatan. Tingkat kerusakannya adalah $0 \% \leq \mathrm{T} \leq 15 \%$.

b. Peringkat 2 (baik)

Kondisi pohon cukup baik sehingga masih diperlukan perawatan. Tingkat kerusakannya adalah $15 \% \leq \mathrm{T} \leq 30 \%$.

c. Peringkat 3 (buruk)

Kondisi pohon kurang sehat sehingga diperlukan perawatan yang intensif. Tingkat kerusakannya adalah $30 \% \leq \mathrm{T} \leq 50 \%$.

d. Peringkat 4 (sangat buruk) Kondisi pohon terancam mati atau telah mati. Tingkat kerusakannya adalah $\mathrm{T}>50 \%$.

\section{HASIL DAN PEMBAHASAN}

\section{Kondisi Umum Lokasi}

Secara umum Kota Bogor berada pada pada $106^{\circ} 48^{\prime}$ BT dan $6^{\circ} 36^{\prime}$ LS dengan ketinggian yang bervariasi antara 190 sampai 0-2\% (datar) seluas 1.763,94 Ha, 2-15\% (landai) seluas 8.091,27 Ha, 15-25\% (agak curam) seluas1.109,89 Ha, 25-40\% (curam) seluas 764,96 Ha dan $>40 \%$ (sangat curam) seluas 119,94 Ha. Curah hujan rata-rata di wilayah Kota Bogor berkisar antara 3000 sampai dengan $4000 \mathrm{~mm} /$ tahun. Temperatur rata-rata berada pada suhu $26^{\circ} \mathrm{C}$ sampai dengan $40^{\circ} \mathrm{C}$ dengan kelembaban udara $\pm 70 \%$. Kecepatan angin sekitar 2,3 Km/jam dan penyinaran matahari $61,4 \%$ dengan intensitas penyinaran sedang, terik, dan sangat terik.

Keadaan iklim mikro di Jalan KH. Rd. Abdullah bin Nuh juga dipengaruhi oleh banyaknya kendaraan yang melintas di jalan tersebut sehingga menyebabkan suhu meningkat dan menurunnya kelembaban. Hal ini disebabkan oleh banyaknya kendaraan yang melalui jalan tersebut sehingga dapat terjadi peningkatan suhu.

\section{Pengumpulan Data}

Data yang diambil di lapang berupa kondisi fisik pohon, koordinat pohon, dan foto eksisting pohon. Kondisi fisik pohon dicatat di tabel berupa kode pohon, nama lokal, $\mathrm{DBH}$ pohon, tinggi pohon, lebar tajuk, bentuk tajuk, kerusakan oleh hama dan penyakit tanaman, dan kerusakan mekanik. Koordinat pohon diambil menggunakan GPS. Foto eksisting pohon diambil menggunakan kamera digital. 
Tabel 4. Kategori Tingkat Kerusakan Pohon oleh Hama dan Penyakit Tanaman pada Pangkal Akar dan Batang

\begin{tabular}{clc}
\hline No & \multicolumn{1}{c}{ Kerusakan hama dan penyakit } & Nilai \\
\hline 1 & Tidak ada kerusakan hama dan penyakit & 0 \\
2 & Pohon tidak berparasit & 1 \\
3 & Pohon berparasit (jamur, benalu) & 2 \\
4 & Batang kering / lapuk; akar kering / lapuk & 3 \\
5 & Batang busuk; akar busuk & 4 \\
6 & Gerowong / keropos pada batang utama & 5 \\
\hline
\end{tabular}

Sumber: Dinas Pertamanan Kotamadya Jakarta Timur (2006)

Tabel 5. Kategori Tingkat Kerusakan Pohon oleh Hama dan Penyakit Tanaman pada Cabang dan Daun

\begin{tabular}{clc}
\hline No & \multicolumn{1}{c}{ Kerusakan hama dan penyakit } & Nilai \\
\hline 1 & Tidak ada kerusakan hama dan penyakit & 0 \\
2 & Pohon tidak berparasit; ulat; jelaga & 1 \\
3 & Pohon berparasit (jamur, benalu) & 2 \\
4 & Klorosis & 3 \\
5 & Nekrosis & 4 \\
6 & Percabangan lapuk & 5 \\
\hline
\end{tabular}

Sumber: Dinas Pertamanan Kotamadya Jakarta Timur (2006)

Tabel 6. Kategori Tingkat Kerusakan Mekanik Pohon

\begin{tabular}{clc}
\hline No & \multicolumn{1}{c}{ Kerusakan mekanik } & Nilai \\
\hline 1 & Tidak ada kerusakan mekanik & 0 \\
2 & Coret-coret atau reklame & 1 \\
3 & Goresan & 2 \\
4 & Sayatan & 3 \\
5 & Patah cabang & 4 \\
6 & Tersambar petir & 5 \\
\hline
\end{tabular}

Sumber: Dinas Pertamanan Kotamadya Jakarta Timur (2006)

Tabel 7. Tingkat Kerusakan Total Pohon

\begin{tabular}{clc}
\hline No. & \multicolumn{1}{c}{ Kualifikasi } & Kerusakan (\%) \\
\hline 1 & Tidak ada & $0<\mathrm{T} \leq 15$ \\
2 & Sedikit & $15<\mathrm{T} \leq 30$ \\
3 & Banyak & $30<\mathrm{T} \leq 50$ \\
4 & Sangat banyak & $\mathrm{T}>50$ \\
\hline
\end{tabular}

Sumber: Dinas Pertamanan Kotamadya Jakarta Timur (2006)

Data pohon pertama dimulai dari sisi timur ke barat jalan. Setiap pohon yang didata diberi kode-kode unik untuk memudahkan dalam penyusunan data. Kode pohon disusun dari nama jalan, posisi pohon, nama pohon, dan urutan pohon yang didata. Salah satu contoh kode pohonnya yaitu "ABN1RR001". Kode "ABN" meupakan kode untuk nama Jalan KH. Rd. Abdullah bin Nuh. Kode angka " 1 " berarti pohon berada di sebelah kiri jalan atau di bagian utara. Selain angka “1”, juga ada

\section{Hasil Inventarisasi Pohon}

Hasil inventarisasi pohon di Jalan KH. Rd. Abdullah bin Nuh diperoleh data sebanyak 1231 pohon (Tabel 8) yang terdiri dari Binato (Cerbera manghas), Biola Cantik (Ficus lyrata), Bunga Sapu Tangan (Maniltoa grandiflora Sceff.), Cemara Kipas (Thuja orientalis), Cermai, Cherry (Muntingia calaburai), Dadap Merah (Erythina cristagali), Kayu Manis (Cinnamomoun burmanii), Kecrutan (Spathodea campanulata), Kenari (Canarium ovatum), Mahoni (Swietenia mahogani Jacq.), Mangga (Mangifera indica), Nangka (Artocarpus integra), Palem Putri (Veitchia merilii), Palem Raja (Roystonea regia), Petai Cina (Leucaena glauca), Pinang (Areca catechu), Tanjung (Mimusoph elengi L.), dan Waru Afrika.

Berdasarkan tingkat kerusakan pohon, terdapat 926 pohon (75.22\%) mengalami kerusakan ringan, 235 pohon $(19.09 \%)$ mengalami kerusakan sedang, 43 pohon (3.49\%) mengalami kerusakan berat, dan 27 pohon $(2.19 \%)$ mengalami kerusakan sangat berat.

Berdasarkan data pada Tabel 8, pohon yang mengalami rusak sangat berat berjumlah 27 pohon $(2.19 \%)$ sehingga pohon dengan kategori ini perlu di tebang dan diganti denga pohon yang baru. Pohon yang mengalami rusak beerat berjumlah 43 pohon (3.49\%) sehingga perlunya perawatan yang intensif, seperti pemangkasan tinggi pohon, pemangkasan lebar tajuk pohon, pengendalian hama dan penyakit tanaman, dan penambalan pada pohon yang berlubang. Lalu pohon yang mengalami rusak sedang atau dalam kondisi cukup sehat berjumlah 235 pohon (19.09\%) sehingga perlu perawatan yang tidak terlalu intensif, seperti penyiraman dan pemupukan. Selanjutnya pohon yang rusak ringan atau dalam kondisi sehat berjumlah 926 pohon $(75.22 \%)$.

\section{Penyusunan Program Aplikasi}

Penyusunan Basis Data dengan $\mathrm{Mi}$ crosoft Access 2010 
Memulai Microsoft Access 2010 dapat dilakukan dengan klik Start $\rightarrow$ AllPrograms $\rightarrow$ Microsoft Office $\rightarrow$ Microsoft Access 2010. Setelah menjalankan Microsoft Access 2010 makan akan ditampilkan Backstage View seperti pada Gambar. Backstage View merupakan jendela awal dan fitur terbaru dari Microsoft Office 2010.

Lalu untuk membuat file basis data baru, dapat dilakukan dengan memilih pilihan Blank Database pada Task Pane atau pilih tombol File $\rightarrow$ New sehingga akan ditampilkan pilihan Blank Database pada Availbale Templates. Pada bagian File Name, ketik nama file basis data yang akan dibuat. Secara defaultMicrosoft Access 2010 akan memberi nama file basis data dengan database1. Selanjutnya tentukan lokasi penyimpanan file dengan menekan tombol browse yang ada di kanan File Name, sehingga akan ditampilkan kotak dialog File New Database. Tentukan lokasi drive dan folder tempat penyimpanan file pada bagian Save in. Pada bagian Save as type tentukan tipe penyimpanan file yaitu Microsoft Access 2007 Databases). Selanjutnya, tekan tombol Create.

Langkah selanjutnya adalah penyusunan struktur basis data. Penyusunan basis data akan menentukan tipe data yang akan dimasukkan, jumlah tabel (table) dan kolom (field), serta hubungan (relationship) antar tabel. Tabel dan kolom disusun berdasarkan klasifikasi yang telah dilakukan.

Pembuatan tabel menggunakan $\mathrm{Mi}$ crosoft Access 2010 dapat dilakukan dengan dua cara, yaitu:

- Melalui jendela Datasheet View, data input dimasukkan terlebih dahulu, baru mengatur struktur tabel.

- Melalui jendela Design View, dimana anda dapat membuat struktur tabel dahulu, baru memasukkan data input.

Pada pembuatan tabel untuk penyusunan basis data digunakan cara melalui jendela Design View. Lang-
Tabel 8. Jumlah Pohon Berdasarkan Jenis Pohon dan Tingkat Kerusakan

\begin{tabular}{|c|c|c|c|c|c|}
\hline \multirow{2}{*}{ Jenis Pohon } & \multicolumn{4}{|c|}{ Tingkat Kerusakan $^{\star}$} & \multirow{2}{*}{$\begin{array}{c}\text { Jumlah } \\
\text { Pohon }\end{array}$} \\
\hline & 1 & 2 & 3 & 4 & \\
\hline Bintaro & 7 & 2 & 0 & 0 & 9 \\
\hline (Cerbera manghas) & $77.78 \%$ ** & $22.22 \%$ & $0 \%$ & $0 \%$ & $0.73 \%$ *** \\
\hline Biola Cantik & 1 & 0 & 0 & 0 & 1 \\
\hline (Ficus lyrata) & $100 \%$ & $0 \%$ & $0 \%$ & $0 \%$ & $0.08 \%$ \\
\hline Bunga Sapu Tangan & 1 & 0 & 0 & 0 & 1 \\
\hline (Maniltoa grandiflora Scheff.) & $100 \%$ & $0 \%$ & $0 \%$ & $0 \%$ & $0.08 \%$ \\
\hline Cemara Kipas & 2 & 0 & 0 & 0 & 2 \\
\hline (Thuja orientalis) & $100 \%$ & $0 \%$ & $0 \%$ & $0 \%$ & $0.16 \%$ \\
\hline & 1 & 0 & 0 & 0 & 1 \\
\hline Cermal & $100 \%$ & $0 \%$ & $0 \%$ & $0 \%$ & $0.08 \%$ \\
\hline Cherry & 9 & 3 & 0 & 0 & 12 \\
\hline (Muntingia calaburai) & $75 \%$ & $25 \%$ & $0 \%$ & $0 \%$ & $0.97 \%$ \\
\hline Dadap Merah & 1 & 3 & 0 & 0 & 4 \\
\hline (Erythina cristagali) & $25 \%$ & $75 \%$ & $0 \%$ & $0 \%$ & $0.32 \%$ \\
\hline Kayu Manis & 134 & 0 & 0 & 0 & 134 \\
\hline (Cinnamomoun burmanii) & $100 \%$ & $0 \%$ & $0 \%$ & $0 \%$ & $10.89 \%$ \\
\hline Kecrutan & 0 & 0 & 0 & 10 & 10 \\
\hline (Spathodea campanulata) & $0 \%$ & $0 \%$ & $0 \%$ & $100 \%$ & $0.81 \%$ \\
\hline Kenari & 423 & 108 & 42 & 7 & 580 \\
\hline (Canarium ovatum) & $72.93 \%$ & $18.62 \%$ & $7.24 \%$ & $1.21 \%$ & $47.12 \%$ \\
\hline Mahoni & 11 & 1 & 0 & 1 & 13 \\
\hline (Swietenia mahogany Jacq.) & $84.62 \%$ & $7.69 \%$ & $0 \%$ & $7.69 \%$ & $1.06 \%$ \\
\hline Mangga & 1 & 0 & 0 & 0 & 1 \\
\hline (Mangifera indica) & $100 \%$ & $0 \%$ & $0 \%$ & $0 \%$ & $0.08 \%$ \\
\hline Nangka & 2 & 1 & 0 & 0 & 3 \\
\hline (Artocarpus integra) & $66.67 \%$ & $33.33 \%$ & $0 \%$ & $0 \%$ & $0.24 \%$ \\
\hline Palem Putri & 155 & 1 & 0 & 1 & 157 \\
\hline (Veitchia merilii) & $98.73 \%$ & $0.64 \%$ & $0 \%$ & $0.64 \%$ & $12.75 \%$ \\
\hline Palem Raja & 41 & 105 & 0 & 3 & 149 \\
\hline (Roystonea regia) & $27.52 \%$ & $70.47 \%$ & $0 \%$ & $2.01 \%$ & $12.10 \%$ \\
\hline Petai Cina & 4 & 4 & 1 & 0 & 9 \\
\hline (Leucaena glauca) & $44.44 \%$ & $44.44 \%$ & $11.12 \%$ & $0 \%$ & $0.73 \%$ \\
\hline Pinang & 123 & 7 & 0 & 5 & 135 \\
\hline (Areca catechu) & $91.11 \%$ & $5.19 \%$ & $0 \%$ & $3.7 \%$ & $10.97 \%$ \\
\hline Tanjung & 6 & 0 & 0 & 0 & 6 \\
\hline (Mimusoph elengi L.) & $100 \%$ & $0 \%$ & $0 \%$ & $0 \%$ & $0.49 \%$ \\
\hline Waru Afrika & 4 & 0 & 0 & 0 & 4 \\
\hline Wvaru Airika & $100 \%$ & $0 \%$ & $0 \%$ & $0 \%$ & $0.32 \%$ \\
\hline Total & 926 & 235 & 43 & 27 & 1231 \\
\hline Iotal & $75.22 \%$ & $19.09 \%$ & $3.49 \%$ & $2.19 \%$ & $100.00 \%$ \\
\hline
\end{tabular}

* : Kategori tingkat kerusakan pohon, (1)Ringan, (2)Sedang, (3)Berat, dan (4)Sangat Berat.

** : Perbandingan pohon bintaro yang rusak pada kategori 1 dengan jumlah pohon bintaro.

kah untuk membuat tabel melalui jendela Design View adalah:

- Dari jendela database, klik tombol Table Design pada grup Tables dalam tab Create.

- Membuat struktur tabel dengan mengisi Field Name (nama kolom), Data Type (tipe data), dan Description (keterangan dari field yang dibuat).

Tabel yang dibuat untuk penyusunan basis data adalah:

1. Tabel Tblinput, merupakan tabel induk yang terdiri dari field ID, Kode Pohon, Nama Lokal, Nama Ilmiah, Koordinat X, Koordinat $\mathrm{Y}$, Tinggi $\mathrm{m}$, Tinggi, Diameter $\mathrm{cm}$, Diameter, Lebar Tajuk m, Lebar Tajuk, Bentuk Tajuk, Tingkat Kerusakan HPTab, Tingkat Kerusakan HPTcd, Tingkat Kerusakan HPT, Tingkat Kerusakan Mekanik, dan Tingkat Kerusakan Pohon.

2. Tabel TblPohon, merupakan tabel yang terdiri dari field ID, Nama
Lokal, Nama Ilmiah dan Bentuk Tajuk.

3. Tabel TblLokasi, merupakan tabel yang terdiri dari field ID, Nama Jalan, dan Nama Kota.

4. Tabel TblKoordinat, merupakan tabel yang terdiri dari filed ID, Kode Pohon, Koordinat $X$, dan Koordinat $\mathrm{Y}$.

5. Tabel TblUser, merupakan tabel yang terdiri dari field ID, UserName, Password, First Name, Last Name dan Level User.

Setelah membuat tabel kemudian membuat Relationships (hubungan) tabel-tabel. Dalam membuat relationships dibutuhkan satu tabel yang akan menjadi parent table (tabel induk) dan tabel-tabel lainnya akan menjadi child table (tabel anak). Dalam basis data ini, tabel Tblinput yang akan menjadi parent table dan tabel TblPohon, TblLokasi, dan TblKoordinat akan menjadi child table (Gambar 3). 
Penyusunan Aplikasi Inventarisasi Pohon Menggunakan Microsoft Visual Basic 2010

\section{A. Penyusunan properti Form Apli- kasi Inventarisasi Pohon}

Form adalah suatu media interaksi antara pengguna dengan aplikasi. Form dikategorikan menjadi dua kategori, yaitu form dinamis dan form statis. Form dinamis adalah form yang bisa dimanipulasi atau diubah bentuk serta disisipi komponenkomponen yang berisi perintahperintah yang diperlukan oleh suatu aplikasi, contohnya windows, web, smart device, database, report, dan wcf (windows communication foundation). Form statis adalah form yang tidak dapat dimanipulasi atau diubah bentuk serta disisipi komponen. Form ini hanya dapat dipanggil melalui perintah kode, contohnya form messagebox dan form inputbox.

Pada aplikasi ini disusun dengan kedua kategori form tersebut, yaitu form dinamis dan form statis. Komponen yang diperlukan untuk menyusun form, antara lain:

- Label, adalah objek kontrol yang dapat menampilkan output tetapi tidak dapat diberikan input pada saat aplikasi dijalankan.

- Textbox, adalah objek kontrol yang dapat diberikan input pada saat aplikasi dijalankan.

- Button, adalah objek kontrol yang dapat mengeksekusi perintah-

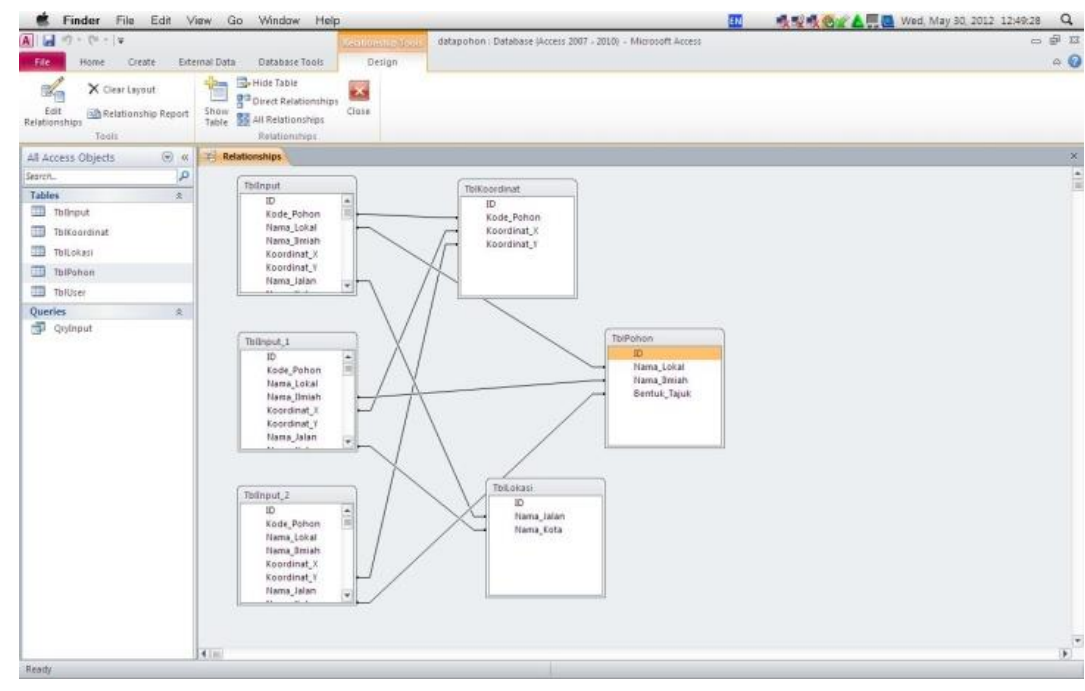

Gambar 3. Relationships tabel-tabel

perintah yang telah dibuat pada jendela kode program.

- Groupbox, adalah komponen yang berfungsi mengelompokkan beberapa komponen agar telihat lebih rapi ditambah dengan adanya keterangan berupa label teks diatasnya.

- Checkbox, adalah komponen yang berfungsi untuk memilih beberapa item data.

- Radiobutton, adalah komponen yang berfungsi untuk memilih satu pilihan dari beberapa pilihan item yang ada.

- Combobox, adalah komponen yang dapat digunakan untuk menampilkan daftar item dengan menu pilihan dropdown.

- Listbox, adalah komponen yang dapat menampilkan daftar item secara keseluruhan,

- Folderbrowsedialog, adalah komponen yang dapat digunakan untuk menampilkan daftar drive folder yang ada pada suatu komputer.

- Picturebox, adalah komponen yang dapat digunakan untuk menampilkan suatu gambar.

- Openfiledialog, adalah komponen yang digunakan untuk menampilkan kotak dialog open file windows.

- Savefiledialog, adalah komponen yang digunakan untuk menampilkan kotak save file dialog windows.

\section{e. Form View.}

Form View digunakan untuk menampilkan lokasi pohon yang ada di lapang dalam sebuah peta digital dan kondisi fisik pohon terkini. Toolbox yang dibutuhkan adalah Label, TextBox, Button, Combobox, dan PictureBox.

\section{f. Form frmGoogleMaps.}

Form View digunakan untuk menampilkan lokasi pohon yang ada di lapang melalui http://maps.google.com 


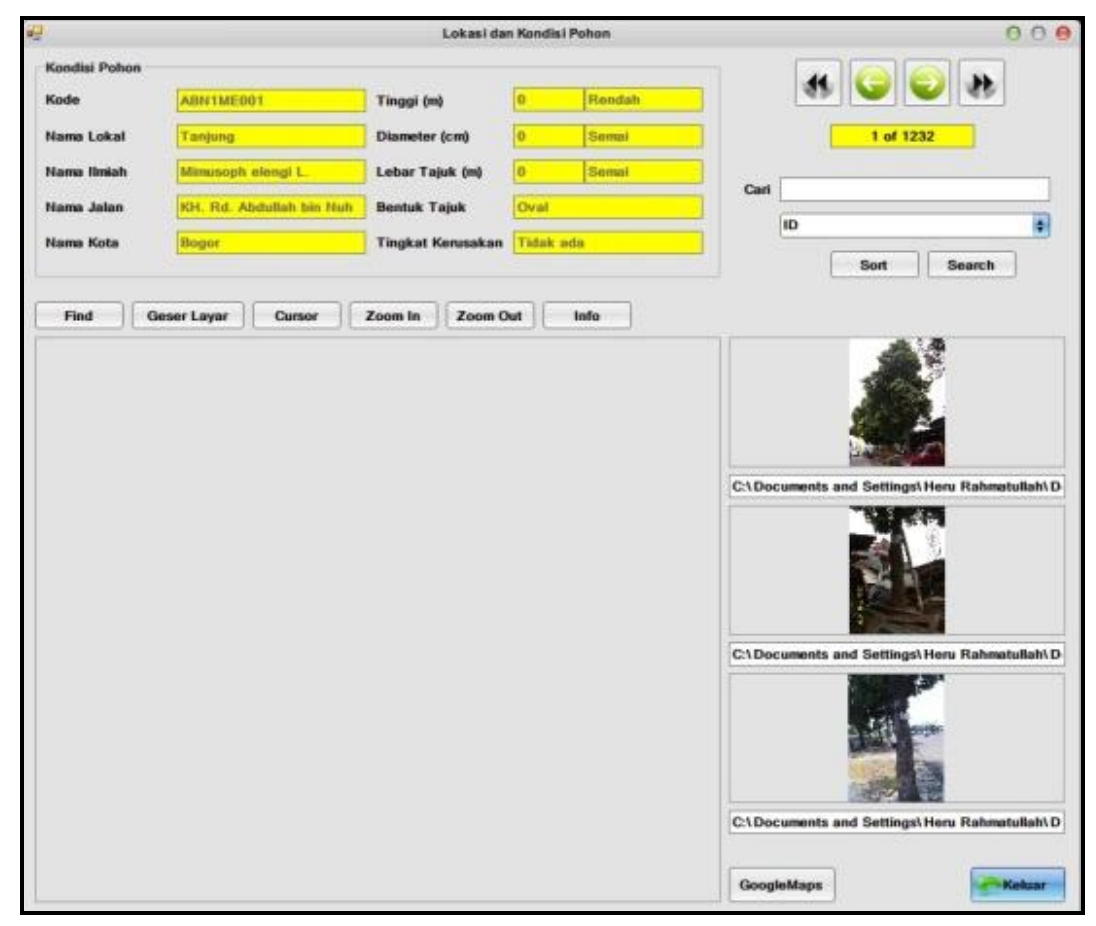

Gambar 8. Form frmView

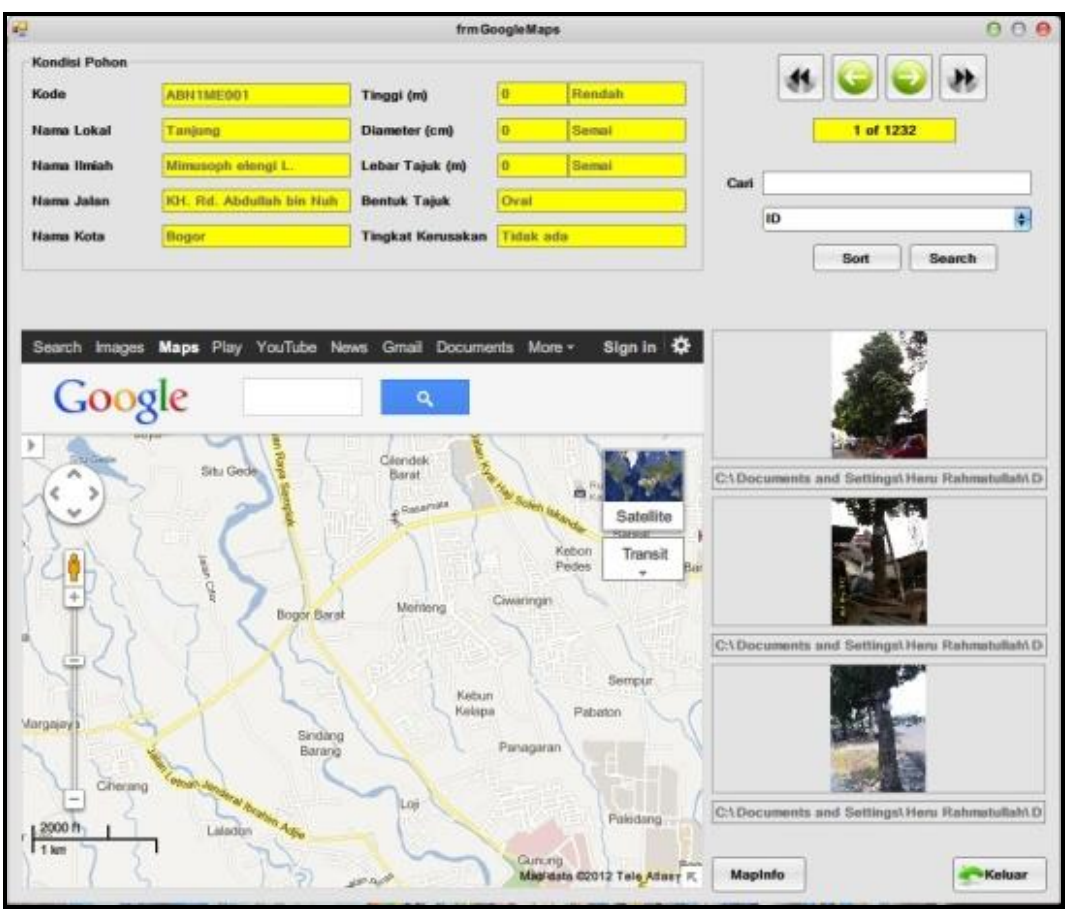

Gambar 9. Form frmGoogleMaps
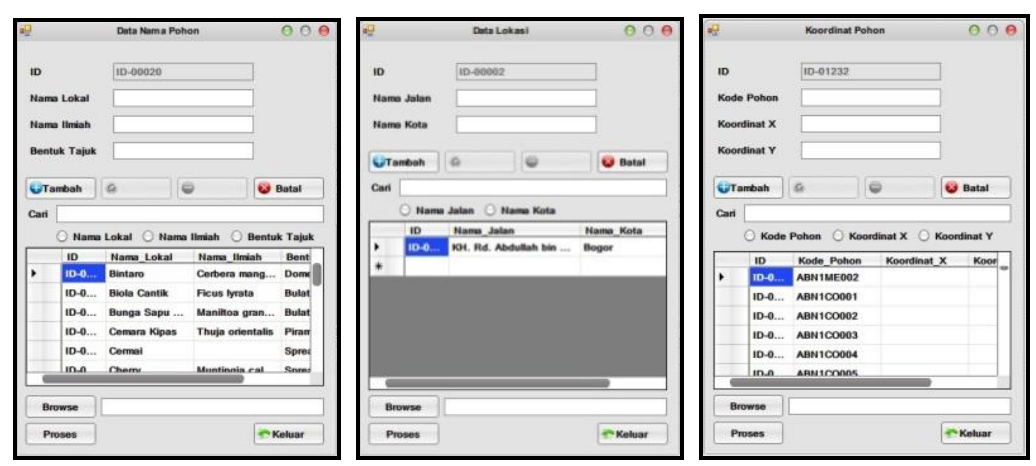

Gambar 10. Form frmPohon, frmLokasi, frmKoordinat
Toolbox yang dibutuhkan adalah $\mathrm{La}$ bel, TextBox, Button, Combobox, dan PictureBox.

\section{g. Form frmPohon.}

Form frmPohon digunakan untuk menambahkan data nama lokal, nama ilmiah, dan bentuk tajuk pohon yang ada di lapang. Toolbox yang dibutuhkan adalah Label, TextBox, Button, DataGridView.

h. Form frmLokasi.

Form frmLokasi digunakan untuk menambahkan data nama jalan dan nama kota lokasi pohon yang ada di lapang. Toolbox yang dibutuhkan adalah Label, TextBox, Button, DataGridView.

\section{i. Form frmKoordinat.}

Form frmKoordinat digunakan untuk menambahkan data kode pohon, koordinat $\mathrm{x}$, dan koordinat $\mathrm{y}$ pohon yang didata. Toolbox yang dibutuhkan adalah Label, TextBox, Button, DataGridView.

j. Form frmJumlahPohon.

Form frmJumlahPohon digunakan untuk menampilkan data jumlah pohon berdasarkan nama lokal pohon. Toolbox yang dibutuhkan adalah Button, GroupBox, DataGridView, dan Chart.

k. Form frmFoto1View.

Form frmFoto1VIew digunakan untuk menampilkan foto pohon dari PictureBox yang terdapat di form frmView. Toolbox yang dibutuhkan adalah Button, PictureBox, dan TextBox.

1. Form frmFoto2View.

Form frmFoto2View digunakan untuk menampilkan foto pohon dari PictureBox yang terdapat di formfrmView. Toolbox yang dibutuhkan adalah Button, PictureBox, dan TextBox. m. Form frmFoto3View.

Form frmFoto3View digunakan untuk menampilkan foto pohon dari PictureBox yang terdapat di form frmView. Toolbox yang dibutuhkan adalah Button, PictureBox, dan TextBox. 


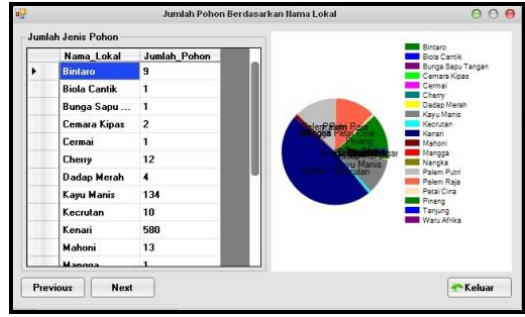

Gambar 11. Form frmJumlah Pohon

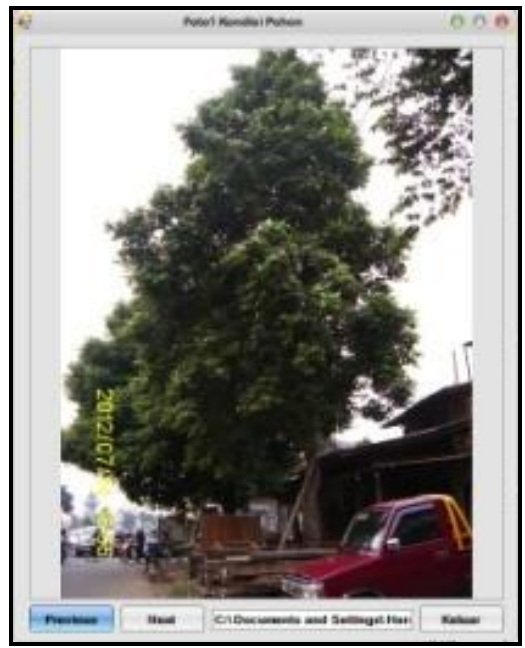

Gambar 12. Form frmFoto1View

n. Form frmFoto1GoogleMaps.

Form frmFoto1GoogleMaps digunakan untuk menampilkan foto pohon dari PictureBox yang terdapat di form frmGoogleMaps. Toolbox yang dibutuhkan adalah Button, PictureBox, dan TextBox.

\section{o. Form frmFoto2GoogleMaps.}

Form frmFoto2GoogleMaps digunakan untuk menampilkan foto pohon dari PictureBox yang terdapat di form frmGoogleMaps. Toolbox yang dibutuhkan adalah Button, PictureBox, dan TextBox.

p. Form frmFoto3GoogleMaps.

Form frmFoto3GoogleMaps digunakan untuk menampilkan foto pohon dari PictureBox yang terdapat di form frmGoogleMaps. Toolbox yang dibutuhkan adalah Button, PictureBox, dan TextBox.

q. Form frmTKPohon.
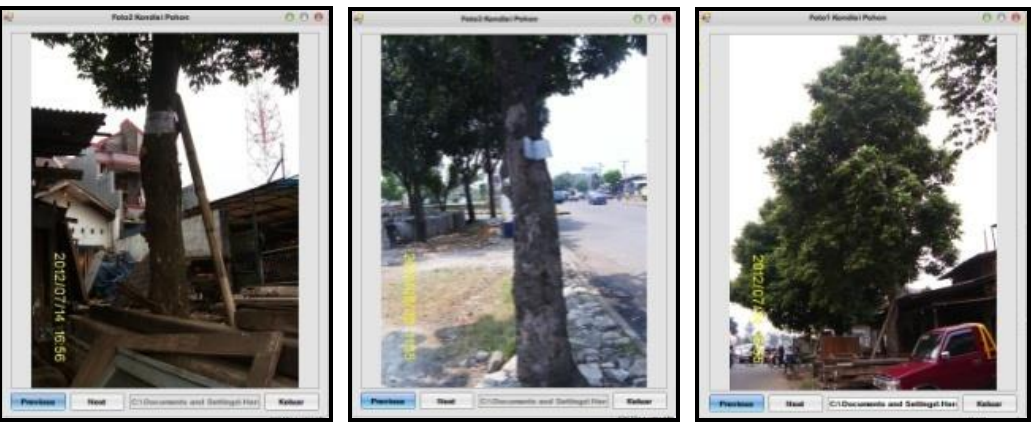

Gambar 13. Form frmFoto2View, frmFoto3View, Form frmFoto1GoogleMaps
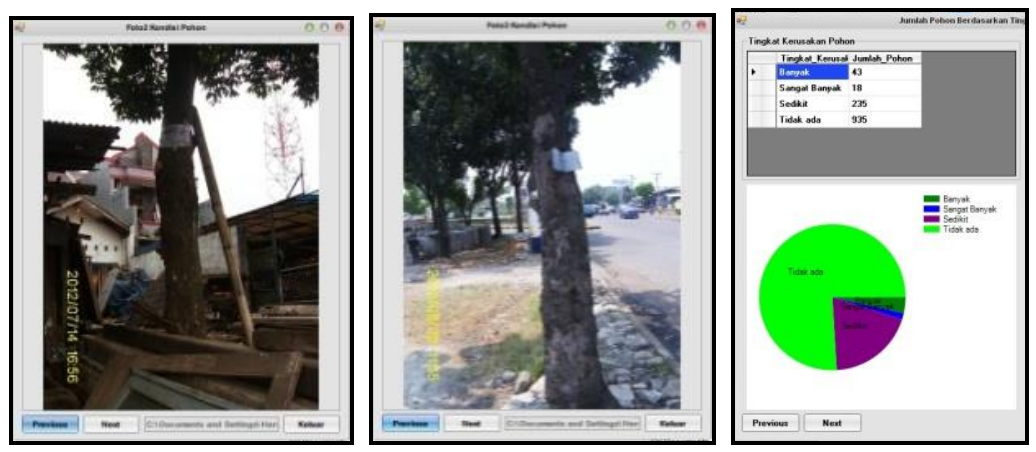

Gambar 20. Form frmFoto2GoogleMaps, frmFoto3GoogelMaps, frmTKPohon

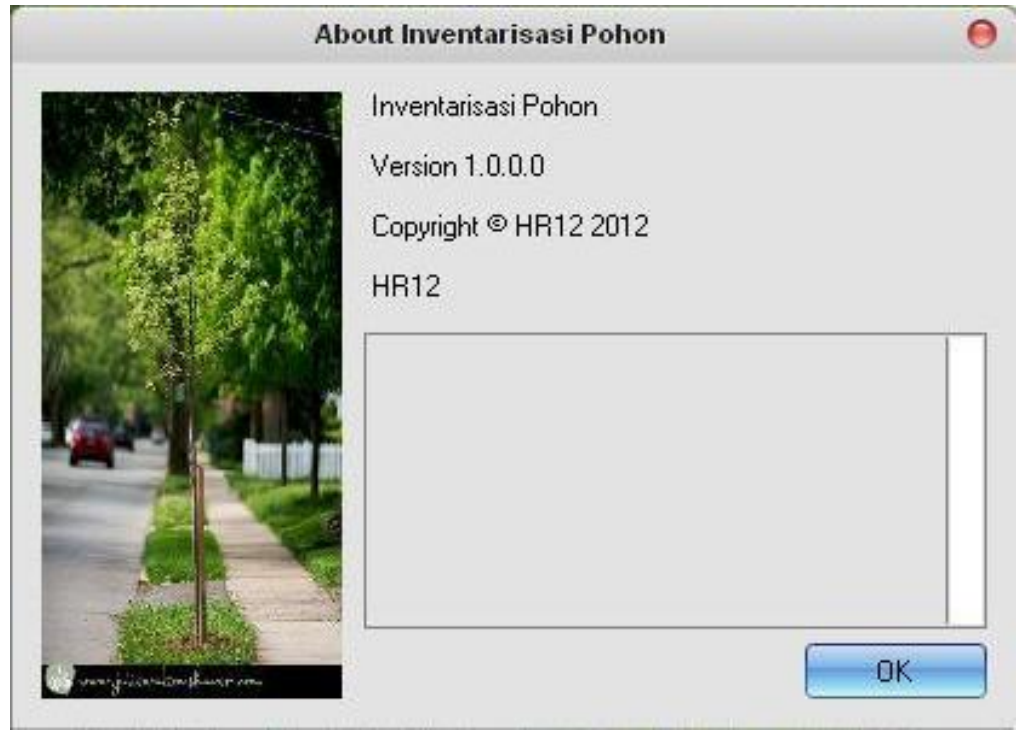

Gambar 10. Form frmPohon, frmLokasi, frmKoordinat

Form frmTKPohon digunakan untuk menampilkan data jumlah pohon berdasarkan tingkat kerusakan pohon. Toolbox yang dibutuhkan adalah Button, ComboBox, TextBox, GroupBox, DataGridView, dan Chart. r. Form frmAbout.

Form frmAbout (Gambar 19) memberi informasi mengenai aplikasi tersebut. Form ini dibuat menggunakan Item Aboutbox.

\section{B. Menambahkan Kode Program}

Penulisan kode program dilakukan setelah pembuatan form selesai. Penulisan kode program ini dila- 
kukan agar tampilan aplikasi yang telah dibuat dapat digunakan oleh user. Kode program pada masingmasing form sesuai fungsi form tersebut. Berikut ini adalah fungsi kode program pada setiap form.

\section{Penyajian Hasil}

Aplikasi inventarisasi pohon dapat digunakan oleh siapa saja, baik masyarakat umum atau pun institusi terkait. Secara khusus, aplikasi ini lebih ditujukan bagi institusi pemerintah yang mengurusi pemeliharaan pohon, contohnya Dinas Pertamanan atau Dinas lain yang terkait pemeliharaan pohon kota.

\section{Membuat File Installer}

Caranya yaitu File installer dibuat dengan mengcopyfile Inventarisasi Pohon.exe dari folder Aplikasi/ bin/Debug/Inventarisasi Pohon.exe ke komputer. Cara lain yaitu dengan membuat file setup.exe. Langkahlangkah membuat file installer atau file setup.exe dari aplikasi inventarisasi pohon adalah:

a. Pada jendela Solution Explorerbagian project aplikasi inventarisasi pohon klik kanan lalu pilih Publish.

b. Setelah itu akan tampilkan kotak dialog Publish, klik tombol Next.

c. Kemudian akan tampil kotak dialog berikutnya dan pastikan pilihan From a CD ROM or DVD $R O M$ dalam keadaan terpilih.

d. Berikutnya klik tombol Next terus sampai pada kotak dialog Publish Wizard yang terakhir klik tombol Finish.

2. Penggunaan Aplikasi Inventarisasi Pohon

Jika aplikasi ini pertama kali dijalankan yang pertama kali muncul adalah form Startup dan dilanjutkan masuk ke form frmLogin. Setelah memasukkan username dan password yang benar, barulah user baru dapat masuk ke form utama, yaitu form frmMenu. Pada form frmMenu merupakan tampilan awal dari aplikasi inventarisasi pohon dan

Tabel 11. Kode Program

\begin{tabular}{|c|c|c|c|}
\hline No & Class / Form & Fungsi & User \\
\hline 1 & Class Koneksi & $\begin{array}{l}\text { Menghubungkan aplikasi ke basis data } \\
\text { Access } 2010 \text {. }\end{array}$ & \\
\hline 2 & Form Startup & $\begin{array}{l}\text { Tampilan awal ketika aplikasi } \\
\text { dijalankan. } \\
\text { Form untuk masuk ke form utama }\end{array}$ & \\
\hline 3 & Form frmLogin & $\begin{array}{l}\text { aplikasi dengan mengisi username dan } \\
\text { password yang benar. }\end{array}$ & Semua User \\
\hline 4 & Form frmMenu & $\begin{array}{l}\text { Form utama aplikasi dan dari form ini } \\
\text { dapat menjuju form yang berfungsi } \\
\text { menambah atau mengedit data yang } \\
\text { telah ada. }\end{array}$ & Semua User \\
\hline 5 & Form frmlnput & $\begin{array}{l}\text { Form untuk menambah dan mengedit } \\
\text { data fisik pohon. }\end{array}$ & Admin, Staf \\
\hline 6 & Form frmView & $\begin{array}{l}\text { Form untuk melihat lokasi pohon di peta } \\
\text { dari MapInfo dan kondisi pohon. }\end{array}$ & $\begin{array}{l}\text { Admin, Staf, } \\
\text { Reguler }\end{array}$ \\
\hline 7 & Form frmGoogleMaps & $\begin{array}{l}\text { Form untuk melihat lokasi pohon di } \\
\text { maps.google.com dan kondisi pohon. } \\
\text { Form untuk menambah dan mengedit }\end{array}$ & $\begin{array}{l}\text { Admin, Staf, } \\
\text { Reguler }\end{array}$ \\
\hline 8 & Form frmPohon & $\begin{array}{l}\text { nama lokal, nama ilmiah, dan bentuk } \\
\text { tajuk pohon. }\end{array}$ & Admin, Staf \\
\hline 9 & Form frmLokasi & $\begin{array}{l}\text { Form untuk menambah dan mengedit } \\
\text { nama jalan dan nama kota lokasi pohon } \\
\text { yang didata. }\end{array}$ & Admin, Staf \\
\hline 10 & Form frmKoordinat & $\begin{array}{l}\text { Form untuk menambah dan mengedit } \\
\text { kode pohon dan koordinat pohon. }\end{array}$ & Admin, Staf \\
\hline 11 & Form frmJumlahPohon & $\begin{array}{l}\text { berupa jumlah pohon berdasarkan jenis } \\
\text { pohon. }\end{array}$ & Admin, Staf \\
\hline 12 & Form frmFoto1View & $\begin{array}{l}\text { Form untuk menampilkan foto pohon } \\
\text { dari PictureBox pada form frmView. }\end{array}$ & Admin, Staf \\
\hline 13 & Form frmFoto2View & $\begin{array}{l}\text { Form untuk menampilkan foto pohon } \\
\text { dari PictureBox pada form frmView. }\end{array}$ & $\begin{array}{l}\text { Admin, Staf, } \\
\text { Reguler }\end{array}$ \\
\hline 14 & Form frmFoto3View & $\begin{array}{l}\text { Form untuk menampilkan foto pohon } \\
\text { dari PictureBox pada form frmView. }\end{array}$ & $\begin{array}{l}\text { Admin, Staf, } \\
\text { Reguler }\end{array}$ \\
\hline 15 & Form frmFoto1GoogleMaps & $\begin{array}{l}\text { Form untuk menampilkan foto pohon } \\
\text { dari PictureBox pada form } \\
\text { frmGoogleMaps. }\end{array}$ & $\begin{array}{l}\text { Admin, Staf, } \\
\text { Reguler }\end{array}$ \\
\hline 16 & Form frmFoto2GoogleMaps & $\begin{array}{l}\text { Form untuk menampilkan foto pohon } \\
\text { dari PictureBox pada form } \\
\text { frmGoogleMaps. }\end{array}$ & $\begin{array}{l}\text { Admin, Staf, } \\
\text { Reguler }\end{array}$ \\
\hline 17 & Form frmFoto3GoogleMaps & $\begin{array}{l}\text { Form untuk menampilkan foto pohon } \\
\text { dari PictureBox pada form } \\
\text { frmGoogleMaps. }\end{array}$ & $\begin{array}{l}\text { Admin, Staf, } \\
\text { Reguler }\end{array}$ \\
\hline 18 & Form frmTKPohon & $\begin{array}{l}\text { Form untuk melihat hasil inventarisasi } \\
\text { berupa jumlah pohon berdasarkan } \\
\text { tingkat kerusakan pohon. }\end{array}$ & $\begin{array}{l}\text { Admin, Staf, } \\
\text { Reguler }\end{array}$ \\
\hline 19 & Form frmAbout & Form tentang informasi aplikasi. & $\begin{array}{l}\text { Admin, Staf, } \\
\text { Reguler }\end{array}$ \\
\hline
\end{tabular}

memberi pilihan untuk masuk ke form frmInput, form frmView, form frmJumlahPohon, form frmPohon, form frmLokasi, form frmKoordinat, form frmUser, dan form frmAbout. Untuk masuk ke dalam form-form tersebut hanya dengan klik button yang ada di form frmMenu.

Pada form frmInput berfungsi untuk memasukkan data fisik pohon yang ada di lapang dan koordinat pohon. Data yang dimasukkan antara lain, id, kode pohon, nama lokal, nama ilmiah, koordinat $\mathrm{x}$, koordinat $\mathrm{y}$, nama jalan, nama kota, tinggi, diameter, lebar tajuk, bentuk tajuk, tingkat kerusakan hpt pada akar dan batang, tingkat kerusakan hpt pada cabang dan daun, tingkat kerusakan hpt total, tingkat kerusakan mekanik, tingkat kerusakan pohon (\%), tingkat kerusakan pohon, dan foto kondisi pohon.
Tingkat kerusakan dapat langsung terhitung dengan klik buttonhasil pada form. Jika ingin menambah data atau memasukkan data baru pada form langsung klik tombol tambah dan langsung tersimpan dalam basis data. Pada form ini juga dapat menghapus data yang ada, dengan cara klik salah satu data pada datagridview, kemudian klik hapus. Jika ingin mengubah data yang ada, bisa diubah dengan klik dua kali pada data di datagridview, ganti data dengan data yang diinginkan, dan klik ubah.

Form frmView digunakan untuk melihat lokasi dan kondisi fisik pohon. Data yang dapat dilihat dalam form ini adalah kode pohon, nama lokal, nama ilmiah, nama jalan, nama kota, tinggi, diameter, lebar tajuk, bentuk tajuk, foto kondisi pohon, dan lokasi pohon di peta. 
Form frmPohon digunakan untuk menambah data nama lokal, nama ilmiah, dan bentuk tajuk pohon. Untuk menambah data pada form ini dengan klik button tambah setelah mengisi textbox nama lokal, nama ilmiah, dan bentuk tajuk pohon. Lalu pada form ini juga dapat menghapus data dengan klik data pada datagridview yang ingin dihapus dan klik tombol hapus. Jika ingin mengubah data yang ada, bisa diubah dengan klik dua kali pada data di datagridview, ganti data dengan data yang diinginkan, dan klik ubah.

Form frmLokasi digunakan untuk menambah data nama jalan dan nama kota. Untuk menambah data pada form ini dengan klik button tambah setelah mengisi textbox nama jalan dan nama kota. Lalu pada form ini juga dapat menghapus data dengan klik datagridview yang ingin dihapus dan klik tombol hapus. Jika ingin mengubah data yang ada, bisa diubah dengan klik ganda datagridview, ganti data dengan data yang diinginkan, dan klik ubah.

Form frmKoordinat digunakan untuk menambah kode pohon, koordinat $\mathrm{x}$, dan koordinat $y$. Caranya dengan klik button tambah setelah mengisi textbox kode pohon, koordinat $\mathrm{x}$, dan koordinat $y$. Lalu pada form ini juga dapat menghapus data dengan klik data datagridview dan klik tombol hapus. Jika ingin mengubah data yang ada, bisa diubah dengan klik ganda datagridview, ganti data, dan klik ubah.

Form frmUser digunakan untuk menambah data username, password, first name, last name, dan level user. Untuk menambah data pada form ini dengan klik button tambah setelah mengisi data. Lalu pada form ini juga dapat menghapus data dengan klik data pada datagridview yang ingin dihapus dan klik tombol hapus. Jika ingin mengubah data yang ada, bisa diubah dengan klik dua kali pada data di datagridview, ganti data dengan data yang diinginkan, dan klik ubah.
Form frmJumlahPohon digunakan untuk mengetahui jumlah pohon yang terdapat pada lokasi kasus penelitian. Selain mengetahui jumlah pohon, aplikasi ini juga dapat mengetahui jumlah pohon berdasarkan tingkat kerusakan pohon dan tingkat kerusakan per jenis pohon dengan klik button next atau previous untuk menuju form frmTKPohon.

\section{Pembahasan}

\section{Aplikasi Inventarisasi Pohon}

Aplikasi inventarisasi aplikasi ini dibuat menarik dan mudah digunakan oleh user. Tampilan dibuat mudah sehingga apabila user ingin memasukkan dan menambah data, user langsung masuk ke form frmInput dengan klik button Input Data Fisik Pohon. Selain itu, dalam memasukkan data pohon berupa tingkat kerusakan, user tidak perlu menghitung lagi karena telah disediakan tombol untuk menghitung kerusakan, yaitu dengan klik tombol hasil pada form frmInput.

Lalu jika user ingin menambah data pohon, lokasi, dan koordinat user dapat langsung klik tombol yang ada di form frmMenu untuk masuk ke form frmPohon, formfrmLokasi, dan form frmKoordinat. Selain melalui form frmMenu, untuk masuk dan menambah data ke form frmPohon, form frmLokasi, dan form frmKoordinat dapat dilakukan melalui form frmInput dengan cara klik button btnPohon, btnLokasi, dan btnKoordinat.

Pada form frmInput, frmPohon, frmLokasi, frmKoordinat, dan frmView telah tersedia fasilitas untuk mencari data-data tertentu. Pada form frmInput dapat dilakukan pencarian data berdasarkan kode pohon, nama lokal, nama ilmiah, nama jalan, nama kota, dan tingkat kerusakan pohon dengan terlebih dahulu klik radiobutton sesuai data yang ingin dicari. Cara yang sama juga dilakukan pada form frmPohon, frmLokasi, dan frmKoordinat tetapi memiliki dasar pencarian yang berbeda. Lalu pada form frmView, selain dapat mencari data yang diinginkan, form ini juga dapat mengurutkan data berdasarkan nama lokal, nama ilmiah, nama jalan, nama kota, tinggi, diameter, lebar tajuk, bentuk tajuk, dan tingkat kerusakan pohon.

Untuk menemukan lokasi pohon sesuai data yang ditampilkan pada form frmView maka harus dilakukan secara manual yaitu dengan klik button Find dan isikan dengan kode pohon yang dicari.

\section{Aplikasi Inventarisasi Pohon untuk Pengelolaan Pohon Kota}

Inventarisasi pohon bertujuan untuk memudahkan dalam penyusunan jadwal pemeliharaan pohon. Data inventarisasi pohon yang diperlukan antara lain, jenis pohon, kondisi pohon, jumlah pohon, dan lokasi pohon di sepanjang jalan sehingga dengan mudah diketahui secara pasti perubahan jenis, kondisi, jumlah, dan lokasi pohon di lapang. Inventarisasi ini memerlukan waktu yang lama, serta tenaga dan biaya yang cukup besar. Selama ini pengelolaan data inventarisasi pohon dilakukan secara manual, sehingga cukup rumit untuk mengupdate data jika terjadi perubahan jenis, kondisi, jumlah, dan lokasi pohon di lapang. Perubahan-perubahan jenis, kondisi, jumlah, dan lokasi pohon di lapang bisa saja terjadi dalam waktu yang singkat karena aktivitas rencana atau perancangan lanskap maupun oleh proses-proses alami.

Aplikasi inventarisasi pohon ini dapat memasukkan data baik secara manual atau langsung import dari data file yang telah ada dalam format Microsoft Excel. Berdasarkan data dari aplikasi ini (Gambar 29) maka 27 pohon $(2.19 \%)$ mengalami rusak sangat berat atau beberapa pohon telah mati maka diperlukan penebangan pohon, 43 pohon $(3.49 \%)$ mengalami rusak berat dan perlu perawatan intensif, 235 pohon (19.09\%) mengalami rusak sedang, dan 926 pohon $(75.22 \%)$ mengalami rusak ringan atau pohon dalam 
kondisi sehat. Detail dari kerusakan pohon dapat dilihat pada form frmInput (Gambar 16), sehingga instansi yang terkait dapat melakukan tindakan yang tepat untuk mengatasi kerusakan pohon.

\section{SIMPULAN}

Aplikasi inventarisi pohon telah disusun dengan menggunakan softwareMicrosoft Access 2010 sebagai penyimpan data, Microsoft Visual Basic 2010 sebagai pembuat tampilan aplikasi dan penyusunan aplikasi, MapInfo Professional 11.0 sebagai penyaji data spasial. Aplikasi ini dibuat untuk menginventarisasi pohon dengan skala kota dan jumlah data yang dapat diinput sebesar 99.999 pohon

Aplikasi ini memiliki kelebihan, berupa tersedianya komponen untuk mencari data, dapat melihat langsung lokasi pohon pada peta melalui googlemaps, komponen dapat langsung menghitung tingkat kerusakan pohon, dan adanya form yang memperlihatkan langsung hasil dari inventarisasi pohon serta tingkat kerusakan pohon serta aplikasi ini memiliki serial number untuk dapat meng-instal-nyadi komputer..

Hasil inventarisasi pohon di Jalan KH. Rd. Abdullah bin Nuh diperoleh data sebanyak 1231 pohon yang terdiri dari 19 jenis pohon, Berdasarkan tingkat kerusakan pohon, terdapat 926 pohon (75.22\%) mengalami kerusakan ringan, 235 pohon $(19.09 \%)$ mengalami kerusakan sedang, 43pohon (3.49\%) mengalami kerusakan berat, dan 27pohon (2.19\%) mengalami kerusakan sangat berat.

\section{DAFTAR PUSTAKA}

Carpenter, P.L., T.D. Walker dan F.O. Lanphear. 1975. Plants in the Landscape. W.H. Freeman and Co. San Fransisco. 481p

Dinas Pertamanan. 2006. Laporan Final Pembangunan Sistem Informasi Manajemen RTH Taman dan Jalur Hijau. Dinas Pertamanan. Jakarta.
Poskota, 2012. Bogor Juga Dilanda Pohon Tumbang.http:// poskota.co.id/b erita-terkini/2012/01/05/bogorjuga-dilanda-pohon-tumbang. Diakses 17 Mei 2012.

Simonds, JO. 1983. Landscape Architecture. McGraw Hill Book Co. New York.

Sadeli, M. 2011. Access 2010 untuk Orang Awam. PT. Maxikom. Palembang.

2011. Visual Basic 2010 untuk Orang Awam. PT. Maxikom. Palembang. 